\title{
Multi-Objective Optimization of Biodiesel and Diethyl Ether Doped Diesel Engine by Taguchi Method
}

\author{
Samet Uslu ${ }^{1}$ \\ 0000-0001-9118-5108 1 \\ ${ }^{1}$ Mechanical Engineering Department, Faculty of Engineering, Karabuk University, Karabuk, 78050, Turkey
}

\begin{abstract}
In present study, it was targeted to optimize multiple impacts of palm oil ratio, diethyl ether (DEE) percentage and engine load on the performance and emissions of a single cylinder diesel engine. The experiments were designed based on the Taguchi $\mathrm{L}_{27}$ orthogonal array which accepts palm oil percentage, DEE ratio and load as variables, brake thermal efficiency (BTE), brake specific fuel consumption (BSFC), nitrogen oxide $\left(\mathrm{NO}_{\mathrm{x}}\right)$ emission and smoke emission as responses. The impacts of engine running factors on responses were defined by analysis of variance (ANOVA). S / N ratio plots were created for each answer to show optimum factor levels. The results showed that the most influential parameters in general on all engine outputs are the load and DEE ratio. Additionally, considering the findings, the best working variables of the engine were determined as 5\% DEE percentage, $6 \%$ palm oil percentage, and $850-$ Watt load. The best BTE, BSFC, $\mathrm{NO}_{\mathrm{x}}$ and smoke emission obtained according to optimum working parameters were found as $30.73 \%, 824.59 \mathrm{~g} / \mathrm{kWh}, 292.20 \mathrm{ppm}$ and $68.91 \%$, respectively. Mean errors between experimental and optimized results were found as $0.46 \%$, $1.75 \%, 3.72 \%$ and $0.16 \%$ for $\mathrm{BTE}, \mathrm{BSFC}, \mathrm{NO}_{\mathrm{x}}$ and smoke emission, respectively. These results showed that the Taguchi design method can be used as an effective tool to determine the impact rates of engine operating parameters and to optimize operating parameters, engine performance and emissions based on the determined impact rates.
\end{abstract}

Keywords: Taguchi design, Optimization approach, Palm Oil, Diethyl ether, Diesel engine

\author{
* Corresponding author \\ Samet Uslu \\ $\underline{\text { sametuslu@karabuk.edu.tr }}$ \\ Adress: Mechanical Engineering De- \\ partment, Faculty of Engineering, \\ Karabuk University, Karabuk, \\ Turkey
}

Researh Article

$\begin{array}{ll}\text { Manuscript } & \\ \text { Received } & 15.07 .2020 \\ \text { Revised } & 24.08 .2020 \\ \text { Accepted } & 31.08 .2020-\end{array}$

Doi: 10.30939/ijastech..770068

\section{Introduction}

Diesel engines are widely used in large sectors of the global economy such as industry, transport and agriculture, due to their high efficiency [1,2]. Despite the high efficiency of diesel engines, their emissions, especially $\mathrm{NO}_{x}$ and smoke emissions, have many negative effects on human health and the environment [3-5]. On the other hand, petroleum-based fuel reserves are running out rapidly due to the increase in the world population and increasing energy demand in parallel with the development of the industry [6]. Studies on diesel engines are carried out for simultaneous reductions of fuel consumption and emissions due to both the depletion of fossil fuel reserves and high emission levels [7]. In this context, environmentally friendly renewable fuel research has accel- erated in recent years and biofuels have emerged as an important alternative to fossil fuels [8,9]. Biodiesel, which has the highest potential to replace fossil fuels among biofuels, is one of the most ideal alternative fuels for diesel engines due to its advantage of being used without any structural changes $[10,11]$. Biodiesel, which has chemical properties close to diesel, is a type of fuel that can be produced from waste, vegetable and animal sources [12-14]. Many types of biodiesel have been used since the inventor of the diesel engine Rudolf Diesel started the diesel engine with peanut oil [15]. In this study, biodiesel fuel obtained from palm oil was used. In the literature, there are many studies in which palm oil biodiesel is mixed with diesel in certain proportions in order to examine the effects on diesel engine. [16-19].

Although biodiesel fuel has many advantages, its pure usage or its high usage can cause incomplete combustion [20]. 


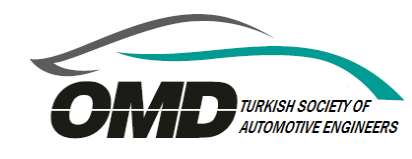

In addition, DEE was added because the viscosity and density of palm oil, which is higher than diesel, would cause problems in spraying the fuel [21]. DEE is a member of fuel additives called cetane developer. It is also considered as biofuel since it can be produced from ethanol [22]. It can improve combustion thanks to its high cetane number and high oxygen content, which is one of its main advantages [23,24]. There are many studies where DEE has been tried by mixing diesel fuel with certain proportions [25-28].

Numerous experiments are needed to determine the suitability of alternative fuels used and to determine the best mixing ratios, as well as to determine their effects on engine emission and performance values. These experimental studies can be time-consuming as well as costly. Therefore, new methods were needed to reduce the number of experiments by giving results with the same accuracy. Computer-aided applications have been used for this purpose. One of the applications used for this purpose is Taguchi design. Taguchi is preferred by many researchers to reduce the number of experiments. Prabhahar et al. [29] used the Taguchi method to determine the optimum blending ratio in the diesel engine, where biodiesel / diesel fuel mixtures are used, to obtain the best BTE, BSFC and emission standards at variable engine load and compression ratio values with few experiments. Sharma et al. [30] studied the alterations on engine responses of a diesel engine employing several biodiesel blends by Taguchi method and optimized the variable levels to accomplish the best engine responses. Manigandan et al. [31] used Taguchi design to determine the optimum conditions of the hydrogen and nano-additive diesel engine. Another purpose of using Taguchi was to maximize BTE while minimizing BSFC and emissions. They stated that the addition of hydrogen and nano-additives improves performance and reduces emissions. Özel et al. [32] investigated the effects of thermal barrier coating on piston and valve surfaces on torque, power and BSFC experimentally and using Taguchi method at different engine loads. According to the results obtained from the study, they emphasized that they found p-values less than 0.05 for all outputs and accordingly obtained statistically significant results.

There are many studies in the literature investigating the effects of using palm oil and DEE on engine performance and emissions by mixing diesel fuels, as mentioned above. However, the optimization study using two fuels is almost nonexistent. Because of the working variables perform a key role on engine outcomes, it is necessary to analyze the combined effect of numerous variables simultaneously on the performance and emissions of the diesel engine. For this reason, in this study, Taguchi design was used to diminish the number of tests to determine the performance and emission outputs of a diesel engine powered by palm oil and DEE, and to optimize the engine operating parameters, performance and emission values based on these operating parameters.

\section{Material and method}

\subsection{Taguchi design}

The Taguchi is an effective instrument that defines optimum variable situations with the lowest number of attempts and reduces time and cost through the experiment [33,34]. Taguchi technique creates statistical design applying vertical columns for optimization of various working variables that affect the process. Fig. 1. illustrates the flow chart of the actions included in this design.

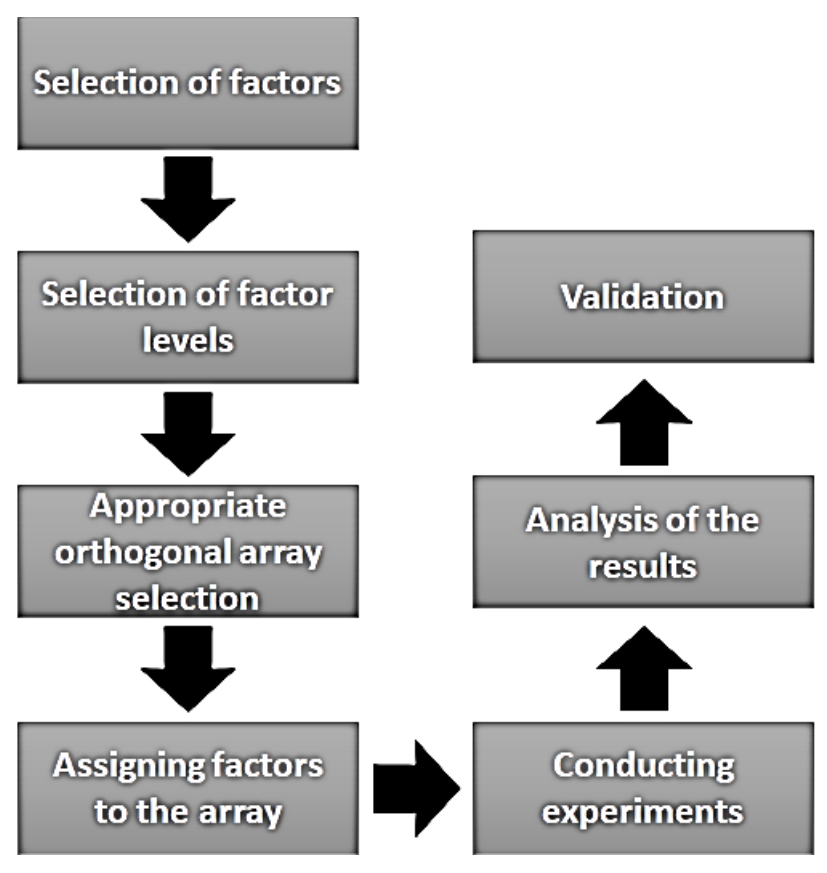

Fig. 1. Flow chart

Taguchi also defines a signal-to-noise ( $\mathrm{S} / \mathrm{N})$ ratio, which provides a measure of the impact of noise factors on performance. A larger $\mathrm{S} / \mathrm{N}$ ratio refers to a system's better performance or quality [35]. There are various $\mathrm{S} / \mathrm{N}$ ratios according to feature types such as 'larger is better', 'smaller is better' and 'nominal is the best'. In this study, 'larger is better' options for BTE and 'smaller is better' for BSFC, $\mathrm{NO}_{\mathrm{x}}$ and smoke emission were used. S / N ratios were acquired using the Eq. (1) and (2) below.

'Larger is better',

$$
S / N=-10 \log _{10}\left[\frac{1}{n} \sum_{i=1}^{n} \frac{1}{y_{i}^{2}}\right]
$$

'Smaller is better',

$$
S / N=-10 \log _{10}\left[\frac{1}{n} \sum_{i=1}^{n} y_{i}^{2}\right]
$$

Here, $n$ test number, $i$ design parameter number and $y_{i}$ represent each test result. 


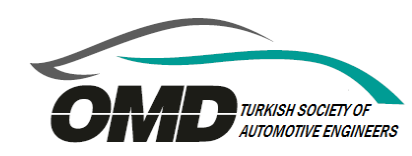

In this research, palm oil ratio, DEE ratio and load were chosen as variables affecting BTE, BSFC, $\mathrm{NO}_{\mathrm{x}}$ and smoke emissions. To analyze the impact of each variable on the selected target, it is scheduled to test the engine with the three levels shown in Table 1, among the selected factors. The ratios of $0 \%, 5 \%$ and $10 \%$ and $0 \%, 2.5 \%$ and $5 \%$ by volume were chosen as three levels of palm oil ratio and DEE ratio, respectively. The three levels of the engine load are set at 750,1000 and 1250-Watt.

Taguchi is a useful instrument to perform the test by changing all factors at the same time and to minimize the total number of tests [33]. The recommended vertical column for three-level factors is the $\mathrm{L}_{27}$ shown in

Table 2. The columns of the orthogonal array $\mathrm{L}_{27}$ demonstrated in

Table 2 are assigned to various variables.

Table 1. Factors and their levels.

\begin{tabular}{c|c|c|c} 
Factors & Level 1 & Level 2 & Level 3 \\
\hline Palm oil ratio (\%) & 0 & 5 & 10 \\
\hline DEE ratio (\%) & 2 & 4 & 6 \\
\hline Load (Watt) & 750 & 1000 & 1250
\end{tabular}

Table 2. $\mathrm{L}_{27}$ orthogonal array.

\begin{tabular}{|c|c|c|c|}
\hline Trial & F1 & F2 & F3 \\
\hline 1 & 1 & 1 & 1 \\
\hline 2 & 1 & 1 & 2 \\
\hline 3 & 1 & 1 & 3 \\
\hline 4 & 1 & 2 & 1 \\
\hline 5 & 1 & 2 & 2 \\
\hline 6 & 1 & 2 & 3 \\
\hline 7 & 1 & 3 & 1 \\
\hline 8 & 1 & 3 & 2 \\
\hline 9 & 1 & 3 & 3 \\
\hline 10 & 2 & 1 & 1 \\
\hline 11 & 2 & 1 & 2 \\
\hline 12 & 2 & 1 & 3 \\
\hline 13 & 2 & 2 & 1 \\
\hline 14 & 2 & 2 & 2 \\
\hline 15 & 2 & 2 & 3 \\
\hline 16 & 2 & 3 & 1 \\
\hline 17 & 2 & 3 & 2 \\
\hline 18 & 2 & 3 & 3 \\
\hline 19 & 3 & 1 & 1 \\
\hline 20 & 3 & 1 & 2 \\
\hline 21 & 3 & 1 & 3 \\
\hline 22 & 3 & 2 & 1 \\
\hline 23 & 3 & 2 & 2 \\
\hline 24 & 3 & 2 & 3 \\
\hline 25 & 3 & 3 & 1 \\
\hline 26 & 3 & 3 & 2 \\
\hline 27 & 3 & 3 & 3 \\
\hline
\end{tabular}

\subsection{Experimental design and fuels}

Test were conducted with different percentages of palm oil $(0 \%, 5 \%$ and $10 \%$ by vol.) and DEE $(0 \%, 2.5 \%$ and $5 \%$ by vol.) at different engine loads (750, 1000 and 1250-Watt). The experimental setup to examine the performance and emissions of a single cylinder, four-stroke, direct injection diesel engine is shown in Figure 2. The test setup includes a loading unit, diesel engine, emission meter, smoke meter, fuel tank and electronic scale. The technical characteristics of the test engine are shown in

Table 3. Transesterification method was used in the production of biodiesel from palm oil. During the production of biodiesel, 1/6 methyl alcohol and sodium hydroxide (1\% by mass of palm oil) as catalysts were used. The properties of the fuels used in the experiments are shown in Table 4.

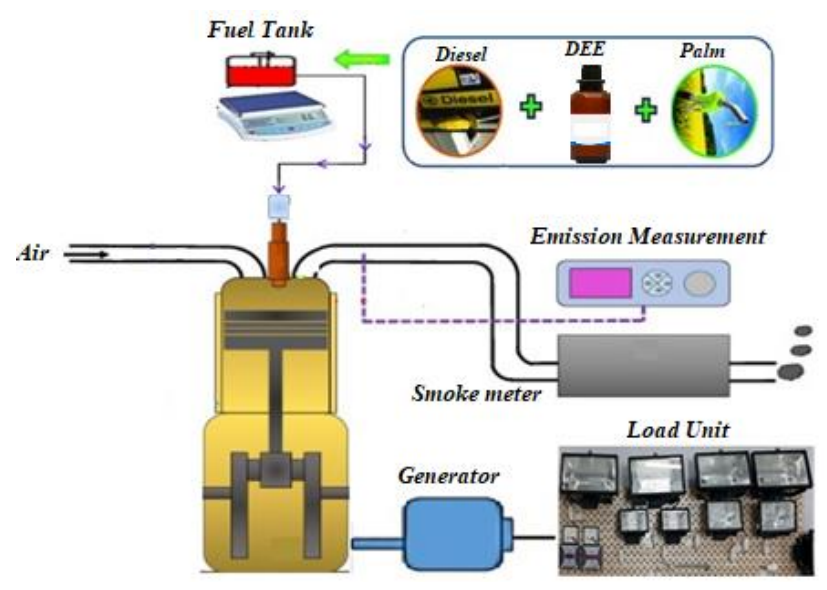

Fig. 2. Schematic view of experimental design.

During measurements, a certain period was waited for the test engine to become stable before measurements were taken. The amount of fuel consumed was measured massively with electronic scales and the consumption time was recorded simultaneously. After determining the amount of fuel spent per hour, BSFC values were obtained by ratio to engine power. Each parameter was measured three times and averaged. BTE $\left(\eta_{e}\right)$ was calculated as shown in Eq. 3 by using BSFC and lower heating value (LHV) of the fuel.

$$
\eta_{e}=\left(\frac{3600}{B S F C \times L H V}\right) \times 100
$$


Table 3. Properties of engine.

\begin{tabular}{l|l} 
Brand & Katana KM 178 FE \\
\hline Type & $\begin{array}{c}\text { 4-stroke, single cylinder, } \\
\text { and direct injection }\end{array}$ \\
\hline Diameter x stroke $(\mathrm{mm})$ & $78 \times 62$ \\
\hline Maximum engine speed $(\mathrm{rpm})$ & 3000 \\
\hline Cylinder volume $\left(\mathrm{cm}^{3}\right)$ & 296 \\
\hline Compression ratio & $18.0: 1$ \\
\hline Ignition advance & $30\left({ }^{\circ} \mathrm{CA}\right)$ \\
\hline Suction & Atmospheric \\
\hline Cooling system & Air cooled
\end{tabular}

Table 4. Technical properties of test fuels.

\begin{tabular}{l|l|l|l} 
& Diesel & $\begin{array}{l}\text { Palm } \\
\text { oil }\end{array}$ & DEE \\
\hline Cetane index & 54 & 64 & 125 \\
\hline Density $\left(\mathrm{kg} / \mathrm{m}^{3}\right)$ & 839 & 880 & 713 \\
\hline Flash point $\left({ }^{\circ} \mathrm{C}\right)$ & 50 & 314 & \\
\hline Kinematic viscosity $\left(\mathrm{mm}^{2} / \mathrm{s}\right)$ & 3.09 & 4.61 & 0.23 \\
\hline Lower calorific value $(\mathrm{kJ} / \mathrm{kg})$ & 43000 & 38500 & 33900
\end{tabular}

\section{Results and Discussions}

ANOVA table and pie chart, which are made to determine the effect rates of selected factors on BTE and which factor is more important, are shown in Table 5 and Fig. 3, respectively. As can be clearly seen from the pie chart, the engine load appears to be the factor with the highest impact $(95.71 \%)$ on BTE. On the other hand, the varying proportions of DEE and palm oil in fuel had no significant effect on BTE. Based on this graph, if it is aimed to increase BTE in the experimental study conducted, it can be interpreted that it is necessary to make changes on engine load more. Also, as shown in the ANOVA table, if the p-value of a variable is greater than 0.05 , it indicates that the effect of that variable is almost negligible. Additionally, high f-values are indicative of high impact. Since the effect of palm oil and DEE remained at low levels, the $\mathrm{p}$ value is expected to be higher than 0.05 and the $\mathrm{f}$ value to be low. On the other hand, since the effect of the engine load is large, it will be expected that the p-value will be low, and the f-value will be high. ANOVA table obtained for BTE supports this, with p-value and f-value results. High engine load means high temperature and pressure in the cylinder. The high temperature and pressure inside the cylinder reveal high combustion efficiency. Therefore, the change of engine load has a direct effect on BTE. The optimum values of the factors that should be used to obtain the best BTE value are shown in Fig. 4 with S / N ratios. Accordingly, for optimum BTE, the engine should be operated at an engine load of $750-\mathrm{W}$ with a fuel mixture containing $4 \%$ DEE and without palm oil.
Table 5. ANOVA for BTE

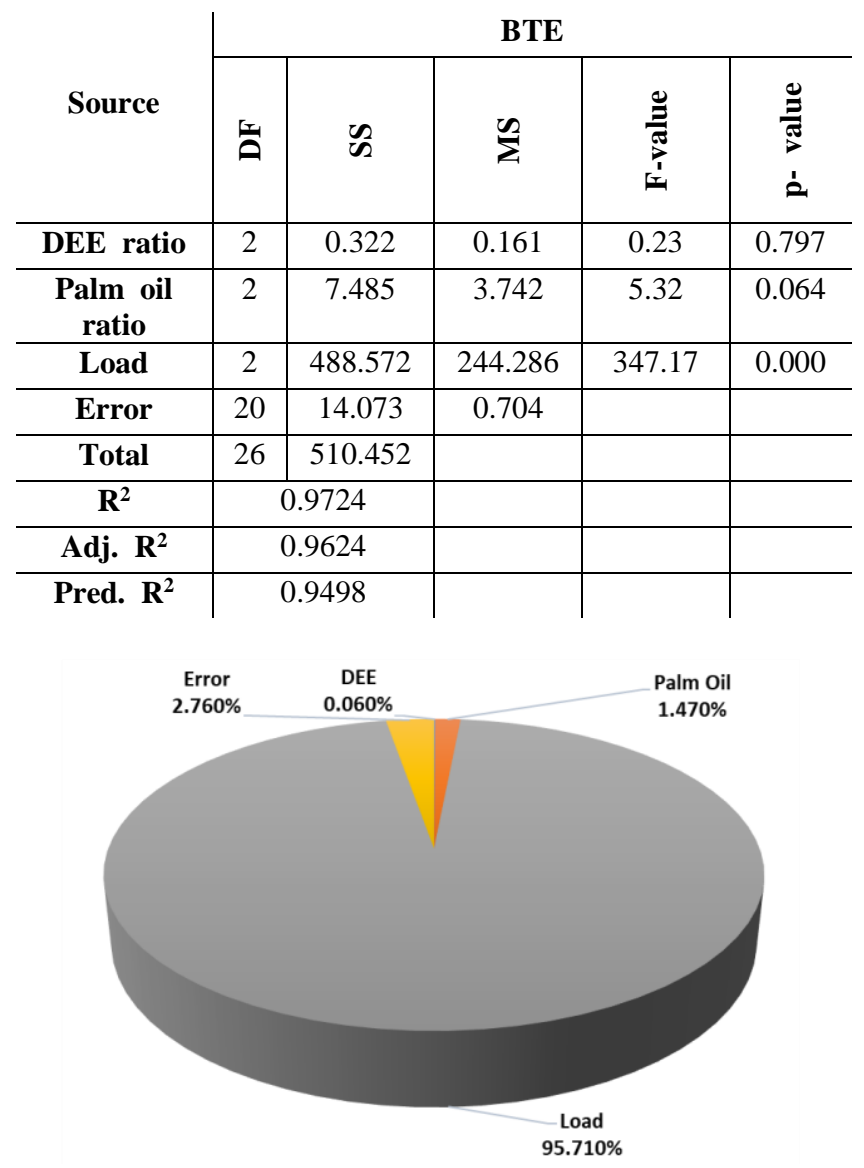

Fig. 3. Effect rates of selected variables on BTE

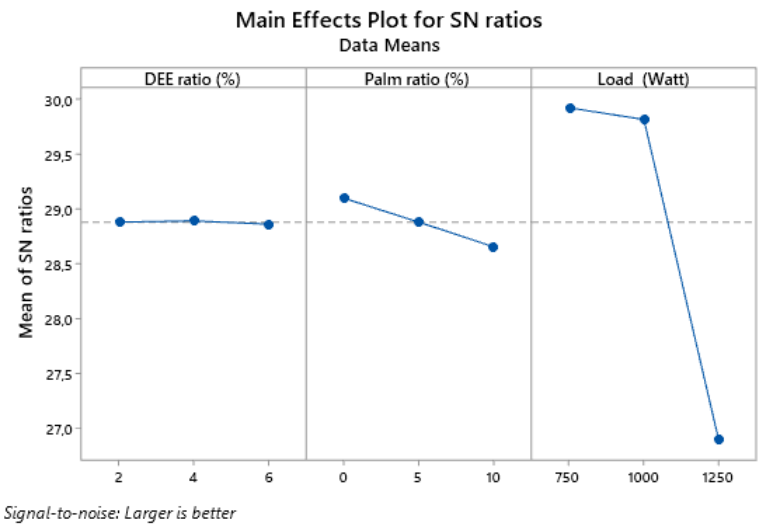

Fig. 4. S/N ratios for BTE

The pie chart and ANOVA table for BSFC are shown in Fig. 5 and Table 6, respectively. According to the ANOVA table, the highest f-value and the lowest p-value were obtained with engine load. If a factor has a high $\mathrm{f}$-value and a 
low p-value, it means it has a high effect on the response. Based on this, it can be said that the parameter that most affects the BSFC is the engine load. The pie chart in Fig. 5 also shows results that support this statement. Engine load has a $66.01 \%$ impact on BSFC. The highest effect after engine load was achieved with DEE ratio as $21.6 \%$. The effect of palm oil remained at a very low level with a rate of $3.22 \%$. Increasing in-cylinder temperature with increasing engine load also reduces the rate of incomplete combustion and hence BSFC decreases. Conversely, if the load decreases, the temperature inside the cylinder decreases and the amount of incomplete combustion increases. This causes an increase in BSFC. Based on this statement, we can say that the engine load has a remarkable effect on the BSFC. On the other hand, the studies in the literature provide us with the information that BSFC generally increases with the use of biofuels, mostly due to their low lower heating values [36-38]. Since there is a biofuel in DEE, the lower heating value of the mixture decreases with the use of DEE. Therefore, BSFC is significantly affected by the change of DEE ratio. Factor levels required for optimum BSFC are given on Fig. 6 which shows $\mathrm{S} / \mathrm{N}$ ratios. Accordingly, optimum BSFC can be achieved with $2 \%$ DEE, $10 \%$ palm oil and $1000-\mathrm{W}$ load.

Table 6. ANOVA for BSFC

\begin{tabular}{|c|c|c|c|c|c|}
\hline \multirow[b]{2}{*}{ Source } & \multicolumn{5}{|c|}{ BSFC } \\
\hline & 告 & $\mathscr{s}$ & $\sum^{\infty}$ & 节 & 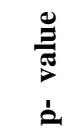 \\
\hline DEE ratio & 2 & 81589 & 40795 & 3.98 & 0.035 \\
\hline $\begin{array}{l}\text { Palm oil } \\
\text { ratio }\end{array}$ & 2 & 22678 & 11339 & 1.11 & 0.351 \\
\hline Load & 2 & 393984 & 196992 & 19.20 & 0.000 \\
\hline Error & 20 & 205183 & 10259 & & \\
\hline Total & 26 & & & & \\
\hline $\mathbf{R}^{2}$ & \multicolumn{2}{|c|}{0.9083} & & & \\
\hline Adj. $R^{2}$ & \multicolumn{2}{|c|}{0.8908} & & & \\
\hline Pred. $\mathbf{R}^{2}$ & \multicolumn{2}{|c|}{0.8684} & & & \\
\hline
\end{tabular}

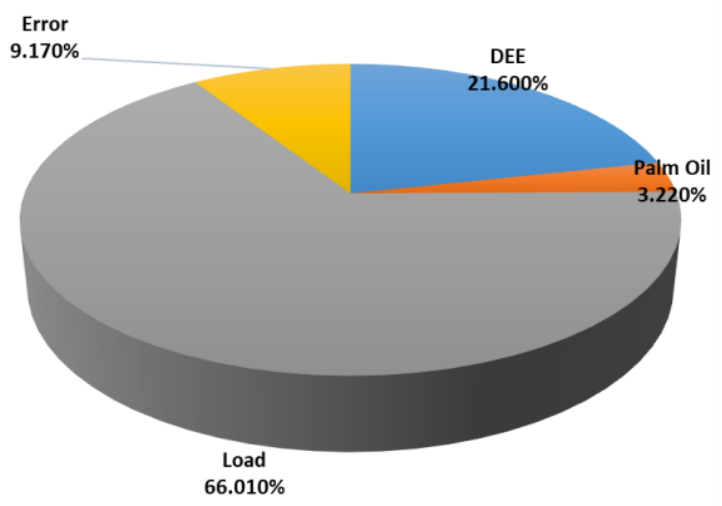

Fig. 5. Effect rates of selected variables on BSFC

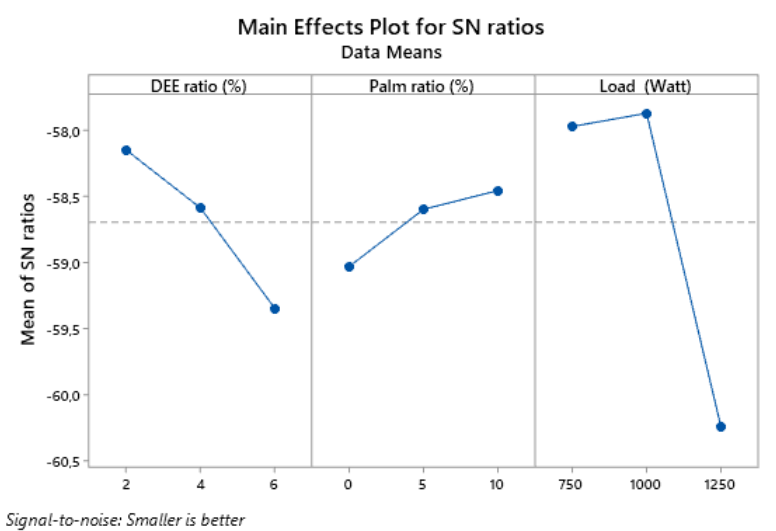

Fig. 6. S/N ratios for BSFC

Considering the ANOVA and pie chart shown in Fig. 7 and

Table 7 for $\mathrm{NO}_{\mathrm{x}}$ emission, DEE and engine load have almost similar effect rates and palm oil has an effect rate close to them but much lower. The effect rates for DEE, load and palm oil were $36.82 \%, 32.63 \%$ and $20.97 \%$, respectively. The magnitude of f-values and p-values was also parallel to these ratios. Due to its oxygen content, DEE not only improves combustion, but also increases the temperature inside the cylinder and provides the oxygen needed for nitrogen atoms to form $\mathrm{NO}_{\mathrm{x}}$. Both cases cause an increase in $\mathrm{NO}_{\mathrm{x}}$ emissions. Otherwise, $\mathrm{NO}_{\mathrm{x}}$ emissions decrease. Thus, it is expected that DEE will have a high impact on $\mathrm{NO}_{\mathrm{x}}$.

It is a known fact that $\mathrm{NO}_{\mathrm{x}}$ emissions occur mostly at high temperatures. Therefore, a parameter affecting the temperature change in the cylinder is expected to have a high impacts rate on the change of $\mathrm{NO}_{\mathrm{x}}$ emission. Since the engine load is a factor that increases the temperature inside the cylinder as it increases, it has a remarkable effect on $\mathrm{NO}_{\mathrm{x}}$. According to the $\mathrm{S} / \mathrm{N}$ ratios shown in Fig. 8, the lowest $\mathrm{NO}_{\mathrm{x}}$ emissions can be achieved with $6 \%$ DEE and without palm oil in the fuel blend at 1000-W engine load.

Table 7. ANOVA for $\mathrm{NO}_{\mathrm{x}}$

\begin{tabular}{|c|c|c|c|c|c|}
\hline \multirow[b]{2}{*}{ Source } & \multicolumn{5}{|c|}{$\mathrm{NO}_{\mathrm{x}}$} \\
\hline & 告 & 2 & $\sum^{\infty}$ & 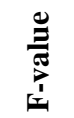 & 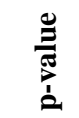 \\
\hline DEE ratio & 2 & 2255 & 1127.7 & 4.40 & 0.026 \\
\hline $\begin{array}{l}\text { Palm oil } \\
\text { ratio }\end{array}$ & 2 & 1134 & 567.1 & 2.21 & 0.136 \\
\hline Load & 2 & 1822 & 911.2 & 3.56 & 0.048 \\
\hline Error & 20 & 5126 & 256.3 & & \\
\hline Total & 26 & & & & \\
\hline$\overline{\mathbf{R}^{2}}$ & & 042 & & & \\
\hline
\end{tabular}




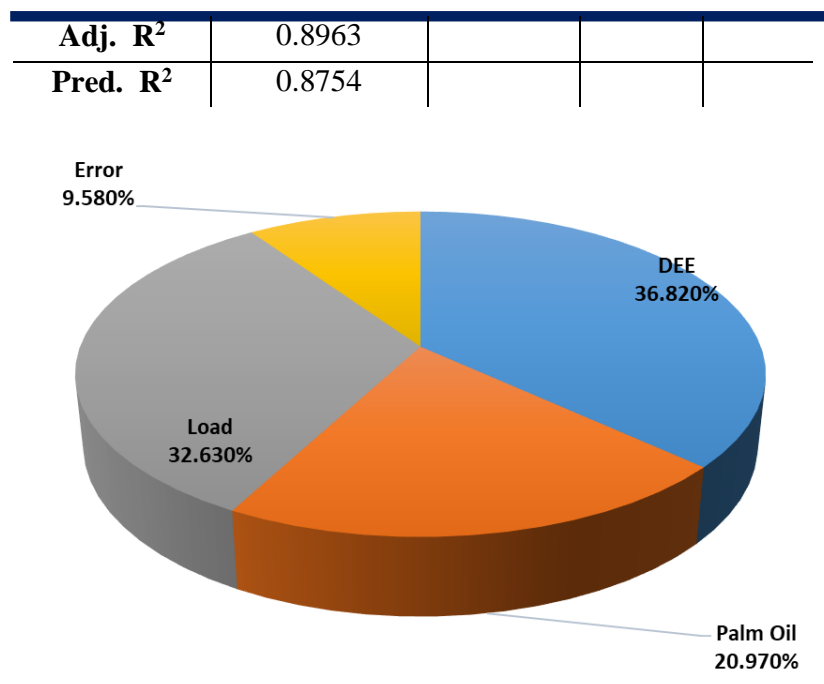

Fig. 7. Effect rates of selected variables on $\mathrm{NO}_{\mathrm{x}}$

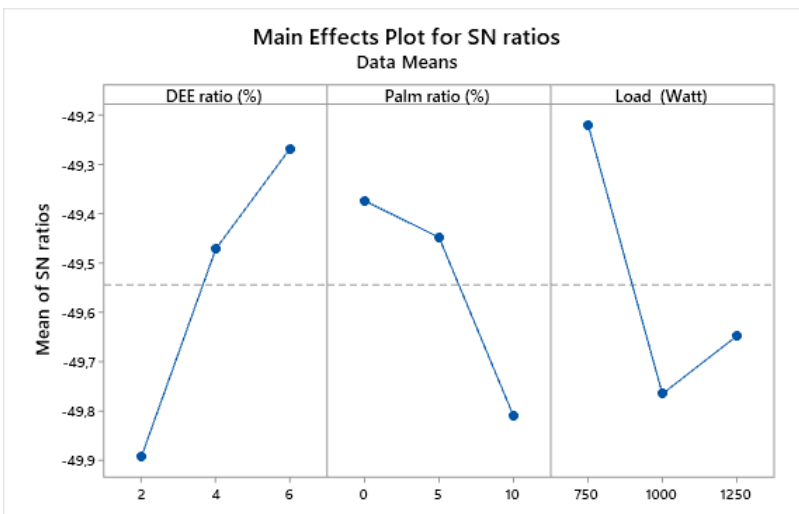

Signal-to-noise: Smaller is better

Fig. 8. S/N ratios for $\mathrm{NO}_{\mathrm{x}}$

Table 8 and Fig. 9 show that the variable with the highest impact on smoke emission is DEE with $49.725 \%$ and engine load followed by DEE with $30.043 \%$. The effect of palm oil remained relatively low compared to other variables with a rate of $11.731 \%$. As seen in the ANOVA table, the resulting p-values and f-values support the effect rates. The amount of oxygen in the cylinder has a big impact on the formation of the smoke emissions. DEE can be effective in reducing smoke emissions thanks to the oxygen it contains. Therefore, it can be said that the change in the amount of DEE has the highest effect on smoke emissions. The optimum values obtained with the $\mathrm{S} / \mathrm{N}$ ratio graph for smoke emissions were determined as $6 \%$ DEE, $10 \%$ palm oil and $1250-\mathrm{W}$ as shown in Fig. 10.
Table 8. ANOVA for Smoke

\begin{tabular}{|c|c|c|c|c|c|}
\hline \multirow[b]{2}{*}{ Source } & \multicolumn{5}{|c|}{ Smoke } \\
\hline & 管 & s & $\sum$ & 莺 & 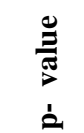 \\
\hline DEE ratio & 2 & 1.7067 & 0.85333 & 32.22 & 0.000 \\
\hline $\begin{array}{c}\text { Palm oil } \\
\text { ratio }\end{array}$ & 2 & 0.3921 & 0.19606 & 7.40 & 0.004 \\
\hline Load & 2 & 1.0244 & 0.51222 & 19.34 & 0.000 \\
\hline Error & 20 & 0.5298 & 0.02649 & & \\
\hline Total & 26 & & & & \\
\hline $\mathbf{R}^{2}$ & & 9150 & & & \\
\hline Adj. $R^{2}$ & & 3820 & & & \\
\hline Pred. $\mathbf{R}^{2}$ & & 3550 & & & \\
\hline
\end{tabular}

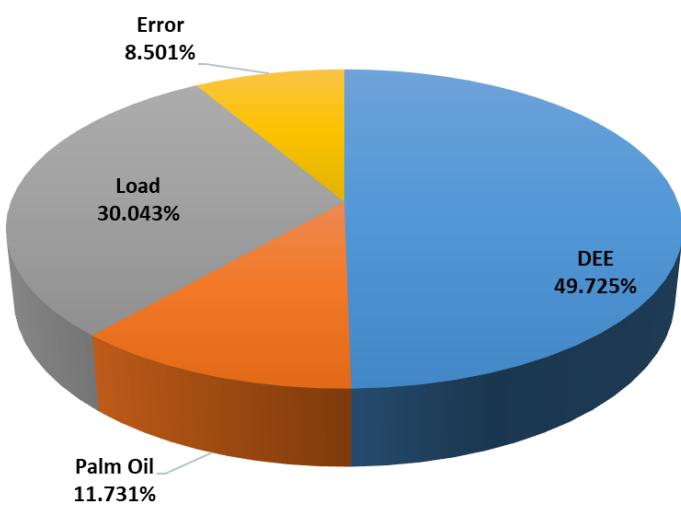

Fig. 9. Effect rates of selected variables on Smoke 


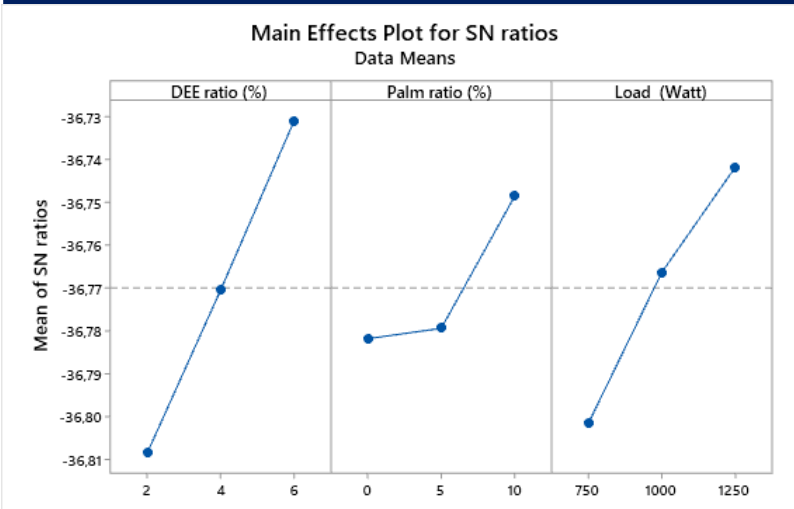

Signal-to-noise: Smaller is better

Fig. 10. S/N ratios for Smoke

\section{Optimization and Validation}

Response optimizer is used to define a single response or combination of input variable settings that optimize a set of responses. In this study, the main purpose of optimization is to maximize BTE while simultaneously minimizing BSFC, $\mathrm{NO}_{\mathrm{x}}$ and smoke emissions. Optimization criteria are shown in Table 9. The optimum engine operating parameters obtained from the optimization and the optimum BTE, BSFC, $\mathrm{NO}_{\mathrm{x}}$ and smoke emission values based on these parameters are shown in Fig. 11. On the left side of each response row in the optimization graph, there is the optimized response (y) and the individual desirability score (d) at the current variable settings. In the upper left corner is the compound desirability (D). The optimum values of the engine operating parameters are shown in red, and the optimum responses arising from these parameters are shown in blue. The optimum values for DEE percentage, palm oil percentage and load were determined as $5 \%, 6 \%$ and 850 -Watt, respectively. The optimum values for BTE, BSFC, $\mathrm{NO}_{\mathrm{x}}$ and smoke emission are $30.73 \%, 824.59 \mathrm{~g} / \mathrm{kWh}, 292.20 \mathrm{ppm}$ and $68.91 \%$ respectively.

Table 9. Optimization criteria

\begin{tabular}{c|c|c|c}
\multirow{2}{*}{ Factors } & \multicolumn{2}{|c|}{ Limits } & \multirow{2}{*}{ Criteria } \\
\cline { 2 - 3 } & $\begin{array}{c}\text { Lower } \\
\text { limit }\end{array}$ & $\begin{array}{c}\text { Upper I } \\
\text { imit }\end{array}$ & \\
\hline DEE ratio (\%) & 2 & 6 & In range \\
\hline Palm oil ratio (\%) & 0 & 10 & In range \\
\hline Load (Watt) & 750 & 1250 & In range \\
\hline BTE (\%) & 20.83 & 32.11 & Maximize \\
\hline BSFC (g/kWh) & 766.03 & 1240.82 & Minimize \\
\hline NOx (ppm) & 271.13 & 331.34 & Minimize \\
\hline Smoke (\%) & 68.26 & 69.35 & Minimize
\end{tabular}

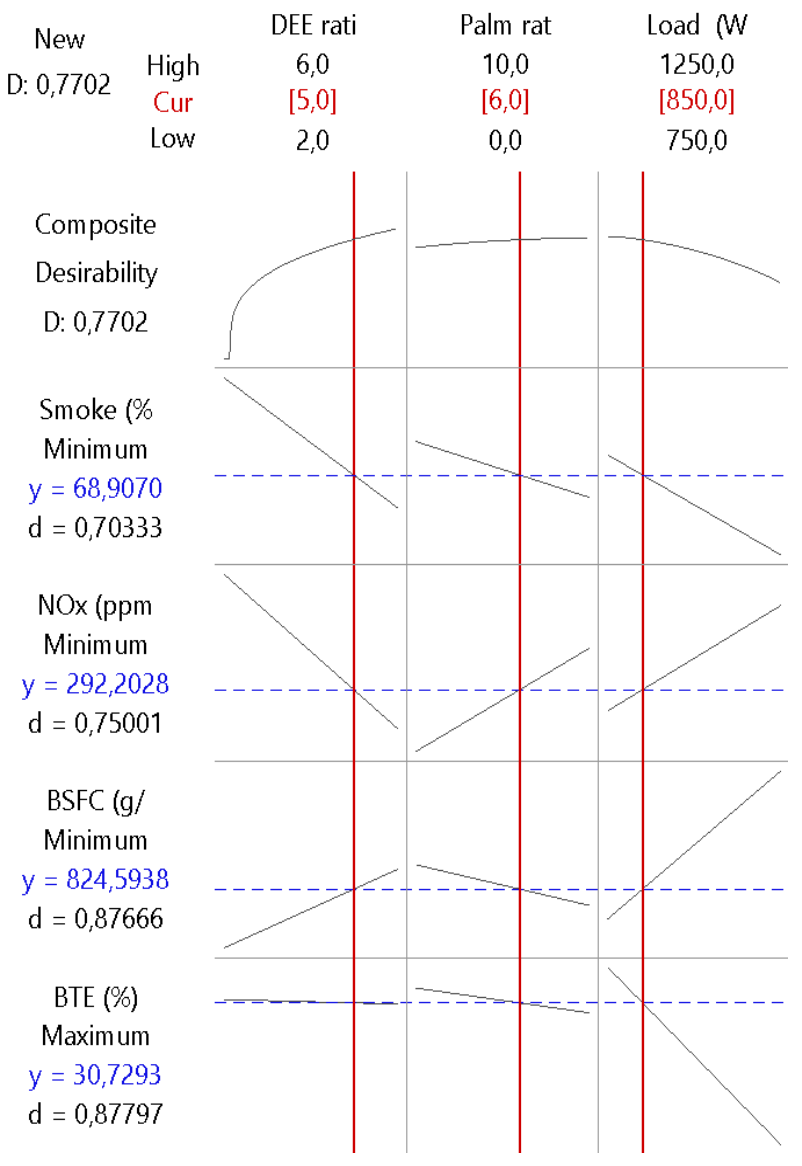

Fig. 11. Optimization results

Optimization results need to be verified. To verify, an experimental study was conducted using the optimum engine parameters obtained from the optimization study. The results obtained from the optimization are compared with the experimental results. This comparison is shown in Table 10 together with the error rates. The error rates were $0.46 \%$, $1.75 \%, 3.72 \%$ and $0.16 \%$ for BTE, BSFC, $\mathrm{NO}_{\mathrm{x}}$ and smoke, respectively.

Table 10. Validation test

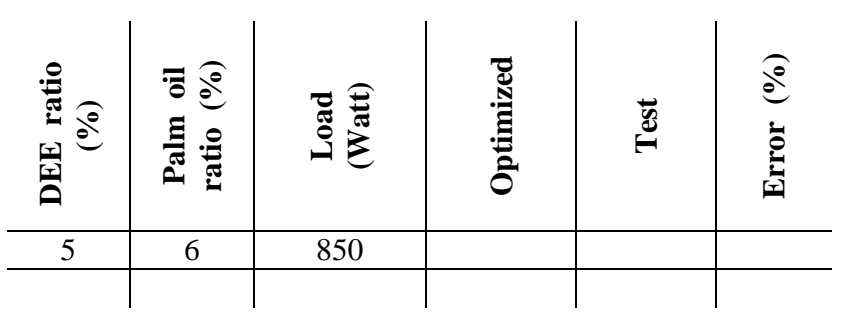




\begin{tabular}{c|c|c|c|c|c}
\hline & & BTE (\%) & 30.73 & 30.59 & 0.46 \\
\hline & $\begin{array}{c}\text { BSFC (g/ } \\
\mathbf{k W h )}\end{array}$ & 824.59 & 810.19 & 1.75 \\
\hline & $\begin{array}{c}\text { NOx } \\
(\mathbf{p p m )}\end{array}$ & 292.20 & 303.07 & 3.72 \\
\hline $\begin{array}{c}\text { Smoke } \\
(\mathbf{\%})\end{array}$ & 68.91 & 69.02 & 0.16
\end{tabular}

\section{Conclusions}

In the present study, experiments are designed based on the Taguchi $\mathrm{L}_{27}$ orthogonal array, which accepts DEE percentage, palm oil percentage and load as factors, BTE, BSFC, $\mathrm{NO}_{\mathrm{x}}$ and smoke emissions in response. An optimization was made to determine the best combination of factors to minimize smoke, $\mathrm{NO}_{\mathrm{x}}$ and $\mathrm{BSFC}$ and simultaneously maximize BTE.

- The specified operating parameters levels are selected as $2 \%, 4 \%$ and $6 \%$ for DEE, $0 \%, 5 \%$ and $10 \%$ for palm oil and 750, 1000 and 1250-Watt for engine load.

- 5\% DEE ratio, $6 \%$ palm oil ratio and $850-\mathrm{W}$ engine load were found as optimum engine operating parameters.

- Optimum results for BTE, BSFC, $\mathrm{NO}_{\mathrm{x}}$ and smoke emission at the optimum operating parameters were found as $30.73 \%, 824.59 \mathrm{~g} / \mathrm{kWh}, 292.20 \mathrm{ppm}$ and $68.91 \%$, respectively.

- Also, the average errors from the verification tests performed to verify the optimization results and the experimental results were $0.46 \%, 1.75 \%, 3.72 \%$ and $0.16 \%$ for BTE, BSFC, $\mathrm{NO}_{\mathrm{x}}$ and smoke, respectively.

As a result, the Taguchi design method can be used as an effective tool to determine the influence rates of engine working variables and to optimize operating parameters, engine performance and emissions based on the determined impact rates.

\section{Nomenclature}

\begin{tabular}{ll}
\hline ANOVA & Analysis of variance \\
BSFC & Brake specific fuel consumption \\
BTE & Brake thermal efficiency \\
d & Individual desirability score \\
D & Compound desirability \\
DEE & Diethyl ether \\
LHV & Lower heating value \\
$\mathrm{NO}_{\mathrm{x}}$ & Nitrogen oxide \\
$\mathrm{R}^{2}$ & Correlation coefficient \\
Adj. $\mathrm{R}^{2}$ & Adjusted correlation coefficient \\
Pred. $\mathrm{R}^{2}$ & Predicted correlation coefficient \\
$\mathrm{S} / \mathrm{N}$ & Signal to Noise
\end{tabular}

\section{$\mathrm{y}$}

Optimized response

\section{References}

[1] Santhosh, K., Kumar, G.N., Radheshyam and Sanjay, P.V., (2020). Experimental analysis of performance and emission characteristics of CRDI diesel engine fueled with 1-pentanol/diesel blends with EGR technique, Fuel, 267.

[2] Simsek, S., (2020). Effects of biodiesel obtained from Canola, sefflower oils and waste oils on the engine performance and exhaust emissions, Fuel, 265, 117026.

[3] Vigneswaran, R., Annamalai, K., Dhinesh, B. and Krishnamoorthy, R., (2018). Experimental investigation of unmodified diesel engine performance, combustion, and emission with multipurpose additive along with water-in-diesel emulsion fuel, Energy Conversion and Management, 172, 370-380.

[4] Pan, H., Li, H., Zhang, H., Wang, A., Jin, D. and Yang, S., (2018). Effective production of biodiesel from non-edible oil using facile synthesis of imidazolium salts-based BrønstedLewis solid acid and co-solvent, Energy Conversion and Management, 166, 534-544.

[5] Simsek, S. and Uslu, S., (2020). Determination of a diesel engine operating parameters powered with canola, safflower and waste vegetable oil-based biodiesel combination using response surface methodology (RSM), Fuel, 270, 117496.

[6] Uslu, S., (2020). Optimization of diesel engine operating parameters fueled with palm oil-diesel blend: Comparative evaluation between response surface methodology (RSM) and artificial neural network (ANN), Fuel, 276, 117990.

[7] Rajak, U., Nashine, P. and Verma, T.N., (2020). Effect of spirulina microalgae biodiesel enriched with diesel fuel on performance and emission characteristics of CI engine, Fuel, 268.

[8] Nanthagopal, K., Ashok, B., Garnepudi, R.S., Tarun, K.R. and Dhinesh, B., (2019). Investigation on diethyl ether as an additive with Calophyllum Inophyllum biodiesel for CI engine application, Energy Conversion and Management, 179, 104-113.

[9] Uslu, S. and Celik, M. B., (2018). Prediction of engine emissions and performance with artificial neural networks in a single cylinder diesel engine using diethyl ether, Engineering Science and Technology, An International Journal, 21 (6).

[10]Yesilyurt, M.K., Yilbasi, Z. and Aydin, M., (2020). The performance, emissions, and combustion characteristics of an unmodified diesel engine running on the ternary blends of pentanol/safflower oil biodiesel/diesel fuel, J Therm Anal Calorim.

[11]Arya, S., Sharma, A., Rawat, M. and Agrawal, A., (2020). Tyre pyrolysis oil as an alternative fuel: A review, Materials Today: Proceedings.

[12]Aydın, M., Uslu, S. and Çelik, M. B., (2020). Performance and emission prediction of a compression ignition engine fueled with biodiesel-diesel blends: A combined application of ANN and RSM based optimization, Fuel, 269.

[13]Yesilyurt, M.K. and Arslan, M., (2019). Analysis of the fuel injection pressure effects on energy and exergy efficiencies of a diesel engine operating with biodiesel, Biofuels, 10 (5), 643- 


\section{5.}

[14]Simsek, S. and Uslu, S., (2020). Experimental study of the performance and emissions characteristics of fusel oil/gasoline blends in spark ignited engine using response surface methodology, Fuel, 277, 118182.

[15]Bari, S. and Hossain, S. N., (2019). Performance and emission analysis of a diesel engine running on palm oil diesel (POD), Energy Procedia, 160, 92-99.

[16]Ge, J. C., Kim, H. Y., Yoon, S. K. and Choi, N. J., (2020). Optimization of palm oil biodiesel blends and engine operating parameters to improve performance and PM morphology in a common rail direct injection diesel engine, Fuel, 260, 116326.

[17]Şanlı, B. G., Uludamar, E. and Özcanl1, M., (2019). Evaluation of energetic-exergetic and sustainability parameters of biodiesel fuels produced from palm oil and opium poppy oil as alternative fuels in diesel engines, Fuel, 258.

[18]Gad, M.S., El-Araby, R., Abed, K.A., El-Ibiari, N.N., El Morsi, A.K. and Ed. G. I., (2018). Performance and emissions characteristics of C.I. engine fueled with palm oil/palm oil methyl ester blended with diesel fuel, Egyptian Journal Of Petroleum, 27 (2), 215-219.

[19]Allami, H. A., Tabasizadeh, M., Rohani, A., Farzad, A. and Nayebzadeh, H., (2019), Precise evaluation the effect of microwave irradiation on the properties of palm kernel oil biodiesel used in a diesel engine, Journal Of Cleaner Production, 241, 1177777.

[20]Heidari-Maleni, A., Gundoshmian, T. M., Jahanbakhshi, A. and Ghobadian, B., (2020). Performance improvement and exhaust emissions reduction in diesel engine through the use of graphene quantum dot (GQD) nanoparticles and ethanol-biodiesel blends, Fuel, 267, 117116.

[21]Uslu, S. and Aydın, M., (2020). Effect of operating parameters on performance and emissions of a diesel engine fueled with ternary blends of palm oil biodiesel/diethyl ether/diesel by Taguchi method, Fuel, 275, 117978.

[22]Di, Y., Ni, Z., Yage, D. I., Zuohua, H., and Zhiyuan, Z., (2010). Flame instability analysis of diethyl ether-air premixed mixtures at elevated pressures Flame instability analysis of diethyl ether-air premixed mixtures at elevated pressures.

[23]Rakopoulos, D. C., Rakopoulos, C. D., Giakoumis, E. G., Papagiannakis, R. G., and Kyritsis, D. C., (2014). Influence of properties of various common biofuels on the combustion and emission characteristics of high-speed DI (direct injection) diesel engine: Vegetable oil, biodiesel, ethanol, $\mathrm{n}$-butanol, diethyl ether, Energy, 73, 354-366.

[24]Lee, S. and Kim, T. Y., (2017). Performance and emission characteristics of a DI diesel engine operated with diesel/DEE blended fuel, Applied Thermal Engineering, 121, 454-461.

[25]Nishanth, S., Gunasekar, N., Nanthakumar, S., Prakash, R. and Kumar, T. S., (2020). Experimental investigation on performance and emission characteristics of VCR engine working with biodiesel and Diethyl Ether, Materials Today: Proceedings.

[26]Yesilyurt, M. K. and A. M., (2020). Experimental investigation on the performance, combustion and exhaust emission characteristics of a compression-ignition engine fueled with cottonseed oil biodiesel/diethyl ether/diesel fuel blends, Energy Conversion and Management, 205.

[27]Uslu, S. and Celik, M. B., (2018). Experimental investigation of the effects of diethyl ether- diesel fuel blends on engine parameters in a low power diesel engine, International Journal of Engineering Sciences \& Research Technology, 7 (5), 1-13.

[28]Loganathan, M., Madhavan, V. M., Balasubramanian, K. A., Thanigaivelan, V., Vikneswaran, M. and Anbarasu, A., (2020). Investigation on the effect of diethyl ether with hydrogen-enriched cashew nutshell (CNS) biodiesel in direct injection (DI) diesel engine, Fuel, 277, 118165.

[29]Prabhahar, M., Prakash, S., George, I., Swaroop and Amith, K.K., (2020). Optimization of performance and emission characteristics of bio diesel fuelled VCR engine using Taguchi approach, Materials Today: Proceedings.

[30]Sharma, A., Ansari, N. A., Singh, Y., Mustefa, I. and Vivekanandhan, C., (2018). Optimization of engine parameters using Polanga biodiesel and diesel blends by using Taguchi method, Materials Today: Proceedings, 5 (14), 28221-28228.

[31]Manigandan, S., Atabani, A.E., Ponnusamy, V.K., Pugazhendhi, A., Gunasekar, P. and Prakash, S., (2020). Effect of hydrogen and multiwall carbon nanotubes blends on combustion performance and emission of diesel engine using Taguchi approach, Fuel, 276, 118120.

[32] Özel, S., Vural, E. and Binici, M., (2020). Optimization of the effect of thermal barrier coating (TBC) on diesel engine performance by Taguchi method, Fuel, 263.

[33]Uslu, S. and Aydın, M., (2020). Effect of operating parameters on performance and emissions of a diesel engine fueled with ternary blends of palm oil biodiesel/diethyl ether/diesel by Taguchi method, Fuel, 275, 117978.

[34]Kumar, R.S., Sureshkumar, K. and Velraj, R., (2015). Optimization of biodiesel production from Manilkara zapota (L.) seed oil using Taguchi method, Fuel, 140, 90-96.

[35]Bose, P. K., Deb, M., Banerjee, R. and Majumder, A., (2013). Multi objective optimization of performance parameters of a single cylinder diesel engine running with hydrogen using a Taguchi-fuzzy based approach, Energy, 63, 375-386.

[36]Raghuvaran, S., Ashok, B., Veluchamy, B. and Ganesh, N., (2020). Evaluation of performance and exhaust emission of C.I diesel engine fuel with palm oil biodiesel using an artificial neural network, Materials Today: Proceedings, In Press.

[37]Shen, X., Shi, J., Cao, X., Zhang, X., Zhang, W., Wu, H. and Yao, Z., (2018). Real-world exhaust emissions and fuel consumption for diesel vehicles fueled by waste cooking oil biodiesel blends, Atmospheric Environment, 191, 249-257.

[38]Aydin, S., (2020). Comprehensive analysis of combustion, performance and emissions of power generator diesel engine fueled with different source of biodiesel blends, Energy, 205, 118074. 